\title{
"Examining the integrity behavior challenges of enforcement officers in Malaysian local government"
}

\begin{tabular}{|c|c|}
\hline \multirow{3}{*}{ AUTHORS } & Mohd Rezal Rasli iD https://orcid.org/0000-0003-3946-2344 \\
\hline & Halimah Abdul Manaf (D http://orcid.org/0000-0001-5391-9887 \\
\hline & Mazlan Ismail \\
\hline ARTICLE INFO & $\begin{array}{l}\text { Mohd Rezal Rasli, Halimah Abdul Manaf and Mazlan Ismail (2020). Examining } \\
\text { the integrity behavior challenges of enforcement officers in Malaysian local } \\
\text { government. Problems and Perspectives in Management, 18(1), 263-277. } \\
\text { doi:10.21511/ppm.18(1).2020.23 }\end{array}$ \\
\hline DOI & http://dx.doi.org/10.21511/ppm.18(1).2020.23 \\
\hline RELEASED ON & Thursday, 19 March 2020 \\
\hline RECEIVED ON & Thursday, 20 June 2019 \\
\hline \multirow[t]{2}{*}{ ACCEPTED ON } & Thursday, 27 February 2020 \\
\hline & $(\mathrm{cc}) \mathrm{EY}_{\mathrm{BY}}$ \\
\hline LICENSE & $\begin{array}{l}\text { This work is licensed under a Creative Commons Attribution } 4.0 \text { International } \\
\text { License }\end{array}$ \\
\hline JOURNAL & "Problems and Perspectives in Management" \\
\hline ISSN PRINT & $1727-7051$ \\
\hline ISSN ONLINE & $1810-5467$ \\
\hline PUBLISHER & LLC "Consulting Publishing Company "Business Perspectives" \\
\hline FOUNDER & LLC "Consulting Publishing Company "Business Perspectives" \\
\hline
\end{tabular}

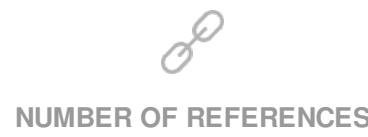

50
NUMBER OF FIGURES

2

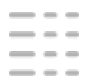

NUMBER OF TABLES

2

(C) The author(s) 2022. This publication is an open access article. 


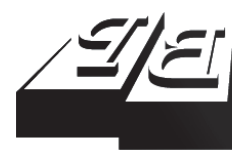

BUSINESS PERSPECTIVES

(O)

LLC "CPC "Business Perspectives" Hryhorii Skovoroda lane, 10, Sumy, 40022, Ukraine www.businessperspectives.org

Received on: $20^{\text {th }}$ of June, 2019 Accepted on: 27 $7^{\text {th }}$ of February, 2020 Published on: $19^{\text {th }}$ of March, 2020

(c) Mohd Rezal Rasli, Halimah Abdul Manaf, Mazlan Ismail, 2020

Mohd Rezal Rasli, Doctoral Student, School of Government, College of Law, Government and International Studies, Universiti Utara Malaysia, Kedah, Malaysia.

Halimah Abdul Manaf, Ph.D., Associate Professor, School of Government, College of Law, Government and International Studies, Universiti Utara Malaysia, Kedah, Malaysia. (Corresponding author)

Mazlan Ismail, Ph.D., Associate Professor, School of Government College of Law, Government and International Studies, Universiti Utara Malaysia, Kedah, Malaysia.
Mohd Rezal Rasli (Malaysia), Halimah Abdul Manaf (Malaysia),

Mazlan Ismail (Malaysia)

\section{EXAMINING THE INTEGRITY BEHAVIOR CHALLENGES OF ENFORCEMENT OFFICERS IN MALAYSIAN LOCAL GOVERNMENT}

\begin{abstract}
There is a call from society to examine the integrity behavior challenges of local government (LG) enforcement officers who work directly with citizens due to the nature of this job. One of the job requirements of enforcement officers is to investigate law enforcement directly to their customers, such as petty traders, hawkers, business owners, developers and contractors, and others. In executing their duties, particularly on law enforcement, high integrity behavior and professionalism of enforcement officers in LG administrative areas of responsibility are necessary. Based on the framework, the study aims to examine the integrity behavior challenges of enforcement officers from the citizens' and staff' perspectives, in particular, on to what extent the officers face the difficulties and challenges in executing their enforcement tasks. Thus, during the study, 30 respondents, namely the citizens and LG staff in Kedah, were surveyed. The data were analyzed using thematic analysis to gain specific dimensions related to integrity behavior. From the citizens' perspective on LG enforcement teams' integrity behavior, challenges were related to main aspects such as biasness, political intervention, and bureaucracy matters. Meanwhile, LG staff consider integrity behavior challenges to be affected by opportunistic attitudes among staff, workforce, and financial issues. The study suggests that enforcement officers should develop soft skills, employability skills, and upgrade academic levels to understand the current situation and develop negotiation skills to deal with grassroots society.
\end{abstract}

Keywords

local government, integrity, behavior, enforcement, instrument, Malaysia

JEL Classification $\quad \mathrm{O} 15$

\section{INTRODUCTION}

The debates regarding enforcement are often linked to the integrity of civil servants in delivering local government (LG) services. The problem of enforcement integrity is very significant at LG level, especially related to taxation as it has a very profound impact on the overall local government administration, the relationship between LG and the local community, management, and relationship between the LG and the higher government administration as an example of the state government and federal government (Beaglehole, 1976; Rosseau, 2010).

The importance of implementing enforcement integrity is often the topic of discussion in developed countries (Erakovich \& Kolthoff, 2016; Jiménez, García-Quesada, \& Villoria, 2014). Thus, the study argued that it should also be given serious attention in developing countries such as Malaysia being in progress to become a developed country. In this regard, the study defines integrity as a way to provide confidence to society by defending a set of values or principles consistently and keep their promises (Yulk, 2009). Therefore, people who execute integrity value can be seen as holding to the promise, the principle, and good value consistently. 
From the enforcement perspective, this aspect of integrity is evaluated in terms of regular exercise of enforcement duties. However, political intervention often causes bias, discrimination against a group, as well as increasingly complicates the bureaucratic process (Colquitt \& Salam, 2009; Danziger, 2007). Although essentially the concept of classical bureaucracy explains that bureaucracy will make the process more systematic and structured, the attitude of individuals who perform such duties causes a particular organization to be viewed as having no integrity (Colquitt \& Salam, 2009; Danziger, 2007).

In general, there are seven main aspects related to integrity. However, most studies use a word "ethics" to be associated with integrity, such as ethics in decision-making, moral development, legal ethics, organizational performance ethics, ethical management, ethical policies, and environmental ethics (Menzel, 2015; Huberts, 2014; Kolthoff, Erakovich, \& Lasthuizen, 2010; Manaf, Armstrong, Lawton, \& Harvey, 2018). Other studies also recommended these aspects, for example, Jiménez, García-Quesada, and Villoria (2014) and McLeod and Harun (2014) demonstrated the theme of ethical management and moral development used to clarify on the construction process of integrity in the public sector.

Jiménez, García-Quesada, and Villoria (2014) who underlie the ethical management from the viewpoint of the local integrity system usage found that the area and community differences in a place provide different value and valuation of integrity. However, overall, the community still assumes that corruption is the foundation that destroys integrity (Erakovich \& Kolthoff, 2016).

In contrast, McLeod and Harun (2014) claim ethical management and integrity from the resource capabilities of a public sector organization. The lack of staff or the absence of efficient and skilled staff will cause ethical management to be inaccessible, and this causes the public community to assume that such inefficiencies are an offense in integrity. If an inefficient staff carry out the enforcement or management of the ethics system, then the process is getting slower, complicated, and sometimes it can cause corruption because the community requires a faster work process.

Based on the problems discussed, the questions that arise in the study are about the challenges faced by LG enforcement teams in discharging their duties with integrity. The contribution of the study will be on adding new knowledge and providing new variables related to the intrapersonal skills and work environment that could affect the effectiveness of enforcement officers in LG. To date, past research related challenges on enforcement integrity in LG is limited, especially in developing countries. Hence, the outcome of this study can be used as a basis for similar challenges on the integrity behavior of enforcement officers, and new programs or culture can be designed to create a model of integrity behavior that suits the enforcement team, particularly in LG work culture in different countries.

\section{LITERATURE REVIEW}

\subsection{Integrity}

The main principle of public administration service delivery is to provide government services based on integrity value. This means that government agencies strive to provide services to society without corruption. The existence of corruption elements in government service administration either at national or international level has affected the competency of a government index (Javier, 2007). The features of cor- ruption have become a global issue that should be addressed immediately to avoid challenges in a country's development.

Huberts (2014) argues that civil service integrity in the democratic system of government should be in line with good values in society. In a healthy democratic rule system, people believe in the integrity of public institutions. Previous studies show that their experience influences the belief in the government in dealing with civil servants, and the extent of the experience in line with the customer expectations of the services received 
(Houston \& Harding, 2013; Boyd-Swan \& Molina, 2019). In this regard, civil servants should pay serious attention to the public's perspective and give priority to public value in delivering the services (Nabatchi, 2012).

In Malaysian context, public should provide the best service to the community. It becomes necessary to strive towards a developed country. Ahmad Sarji Bin Abdul Hamid (1996) states that the old administrative patterns need to be changed to more proactive and sensitive administration of the current community-oriented development through more convergence towards various controls and enforcement by law. The government takes a serious look at ensuring the national administration continues to evolve by taking the approach to improve efficiency and effectiveness in the law enforcement aspects in the country and progress in the public service.

\subsection{Enforcement from local government's and citizens' perspectives}

Baldwin, Cave, and Lodge (2012) suggest improvements in legislation to enhance the effectiveness of enforcement by implementing the processes in legal cycles. They note the following elements in the legal cycle:

1) legal development;

2) strategy planning;

3) granting of permits;

4) monitoring;

5) periodic inspection; and

6) Act of non-compliance.

Keane, Jones, Edwards-Jones, and Milner-Gulland (2008) and Wahani, Hakim, Soeaidy, and Noor (2014) found that there are limited resources to implement law enforcement, monitoring, periodic inspections, and reports frequently to ensure the success of a program.

Macrory (2006) also agreed to the view and mentioned that follow-up monitoring of enforcement is a must for compliance with the law. For example, a study in the Hai Duong region in Vietnam by Binh (2014) showed that by monitoring and control activities practiced in the region, the weaknesses of an organization, the administration bureaucracy at the regional level, and cases of misconduct among government officials could be minimized. Enforcing the monitoring can increase the effectiveness in the legal system indirectly to ensure that the rights of society are based on existing laws.

Meanwhile, in Malaysia, the system was introduced and applied at all district offices known as the Law Enforcement Monitoring System (SPPU) or in Malay known as Sistem Pemantauan Penguatkuasaan Undang-undang (Pekeliling Kemajuan Pentadbiran Awam Bil.1 Tahun, 2001). This system aims to create an integrated method to overcome the problem of law enforcement actions at the district administration level. The effectiveness of this system will be tested by monitoring such legal violations with information obtained to implement enforcement (Laporan Pembahruan dan Kemajuan dalam Perkhidmatan Awam, 2000). This shows that the element of law enforcement is important for nation-building to be comparable to developed countries that have gone through an era of law enforcement transformation.

Various methods are used either from the government or the local community, aimed at addressing problems that arise in providing the best service for the community. The study by Ngah, Zakaria, Mustaffa, and Sawal (2011) suggested that each local government should be stronger in facing the issues of enforcement and various challenges to enhance the image of LG in the eyes of society, especially in Malaysia. Therefore, enforcement actions are seen as one of the methods to realize their dreams to solve problems faced through the services offered.

\subsection{Really Responsive Risk-based Regulation Theory}

The theory is formulated from the Theory of Responsive Regulation developed by Ayres and Braithwaite (1992). The theory describes the enforcement process that needs to be done by stages, and in general, six stages need to be implemented to minimize the failure in the enforcement: license cancellation, license delay, criminal punishment, civil punishment, warning notice, and advice. 
However, as there are various issues of failure in terms of the implementation centered on the theory, and the "risk-based" element is included where the process of implementation has become more dynamic and responsive towards the arising issues (Baldwin, Cave, \& Lodge, 2012; Black \& Baldwin, 2010). Thus, the development of this theory is now known as Really Responsive Riskbased Regulation (Black \& Baldwin, 2010). The change in the theory is dynamic and responsive, where it accounts for risked issues that might arise, and making the implementation flexible based on five criteria (Phang, 2008), namely regulated firms' behavior, attitude, and culture (Rosli, Abd Aziz, Mohd, \& Said, 2015), regulation's institutional environment (Mohamad, Daud, \& Yahya, 2014), interactions of regulatory controls (Said, Alam, \& Khalid, 2016), regulatory performance (Mohamad, Daud, \& Yahya, 2016), and regulatory change (Black \& Baldwin, 2010).

There are six stages in enforcement implementation (as mentioned earlier). However, for the Really Responsive Risk-based Regulation, it is not confined to this process. It is concerned with the issues of risks and local conditions. For example, if an event arises, it can cause a riot or pose a risk in terms of the security; therefore, the enforcement process will not begin at the first stage, which is persuasion, but will proceed directly to civil penalty or criminal penalty (Black \& Baldwin, 2010). Thus, it can be understood that through the Really Responsive Risk-based Regulation, the enforcement process becomes dynamic and flexible based on the risk or condition stated in the five aspects of the theory.

This is followed by the discussion on the Really Responsive Risk-based Regulation to be synthesized together in the literature review to explain how this theory is applied in the context of LG enforcement in Malaysia. The outcome from the respondents of the study will also be integrated with the Really Responsive Risk-based Regulation Theory to find the solution as to harmonize the perspectives of the society with the capability and constraints faced by LG.

The application of Theory of Responsive Regulation can be seen in the case study discussed by Danziger (2007). As Danziger (2007) further illustrated, in the Gamma country, citizen A and citizen B apply for business license, and both are given the same form, pay the same value, and undergo a standard procedure through a fair enforcement process. Thus, in Gamma, an idealistic, classic bureaucratic process can be carried out. In turn, in Delta country, citizen $\mathrm{A}$ is from a dominant ethnic group in the country, but citizen B is from the minority group, and both wish to apply for business license. Citizen A obtains the application form and can apply for the license because he is from a dominant ethnic group, and the clerk giving the form is also from the same ethnic group. However, as for citizen $\mathrm{B}$, the applicant does not get a form because the quota for the applicant's ethnic group is full. However, citizen B has an option to obtain the form and apply it through the top management. The situation in Delta highlights the reality of the bureaucratic process that happens in comparison to the idealistic classic bureaucracy. Under closer observation, Gamma's situation shows a higher level of integrity as compared to Delta, but in a real situation, the process is rather complex and shows that the situation in Delta achieved a higher level of integrity based on the Really Responsive Risk-based Theory (Black \& Baldwin, 2010).

It is because Delta has a pluralistic community, with diverse ethnic populations, that resulted in business applications in the country to be determined based on the quota of the ethnic population. If the dominant ethnic group has a larger quota than the ethnic group, it would be fair principle in the country. This is because the local culture in the country is strong with their respective ethnic values and ethnic differences. The action of implementing the quota system based on ethnicity is known as positive discrimination (Noon, 2010). It means that if the ethnic issues are not dealt with well, riot and racial chaos are bound to take place. Thus, based on the Really Responsive Risk-based Regulation, these ethnic differences will be the "risk-based" that need to be addressed properly; therefore, the proportional quota system should be applied fairly across the ethnic groups (Baldwin, Cave, \& Lodge, 2012; Black \& Baldwin, 2010).

It is also worth understanding that the quota proportion issue is well acknowledged internally by the people delivering the services. However, the 
lack of awareness by the public on the quota system may lead to the assumption of discrimination and bias towards racial groups. These conflicting perspectives between the public and the service deliverers will increase the risk and invite other issues if this is not well handled. Thus, the element of "really responsive" is vital to clarify pertaining issues to the general public in the attempt to address rising risk factors immediately (Baldwin, Cave, \& Lodge, 2012; Black \& Baldwin, 2010). This clearly shows how important it is to harmonize the perspectives of the people with those delivering the services and carrying out the enforcement.

Besides, the Really Responsive Risk-based Regulation Theory is in tandem with the views held by Rosenbloom, Kravchuk, and Clerkin (2014) who stated that in addressing public issues, one perspective would not be deemed as reasonable such as only learning from the perspective of the law, but instead one also needs to consider it from the perspectives of management and politics. This is because the public does not only refer to the law aspect but also various aspects, for instance, discretion, and sentiments to address this issues; therefore, the administrators should acknowledge from three perspectives, namely legal, political, and management (Rosenbloom, Kravchuk, \& Clerkin, 2014). The implementation of the Really Responsive Risk-based Regulation Theory is seen to be in line with all three perspectives, where this theory makes the enforcement process flexible and dynamic as compared to the previous theory, namely the Responsive Regulation Theory, that concerns the legal perspective (Black \& Baldwin, 2010; Rosenbloom et al., 2014).

In terms of the LG enforcement application in Malaysia, for example, the issue of non-licensed food stalls by the roadside. The enforcement method on a non-licensed stall that has just been set up against the abundant non-licensed stalls that have long been around would surely require different processes of enforcement. In particular, in urban areas, people would prefer to eat out as compared to dining in, which leads to these stalls to become popular among urban residents (Ali \& Abdullah, 2012). In this vein, $L G$, in turn, should make sure that the operations of these stalls are under control, and the food stalls are always clean. This is to guarantee that the sellers obey the procedures, and mon- itoring is vital as a form of enforcement. Measures to be taken by the LG for non-licensed stalls (newly set up) must be stricter, which is directly going to the third stage, civil penalty (Ayres \& Braithwaite, 1992; Black \& Baldwin, 2010). The aim is to curb the emergence of non-licensed stalls and prevent enforcement measures from being difficult.

With regard to the stalls that has long been set up that have their loyal customers based on ethnicity, the enforcement method cannot simply use the perspective of the law, but it also has to consider political perspective and management depending on the risk-based degree (Rosenbloom, Kravchuk, \& Clerkin, 2014). Thus, the first method, which is persuasive, is seen to be more appropriate. An alternative solution from the side of the management is considered as compensation or new sites evaluated in terms of the cost-benefit analysis. If there is more than one alternative, the public participation such as voting might be considered to determine the best solution based on the political perspective (Rosenbloom, Kravchuk, \& Clerkin, 2014; Manaf, Mohamed, \& Lawton, 2016). All these processes show that the public enforcement aspects implemented by LG are complex. These must be addressed well, especially from the perspective of the public, and be consistent with the objectives intended by LG. However, often these measures are construed as being biased. Therefore, harmonizing the people's perspectives with those of LG is essential to ensure that the enforcement is smooth and effective.

\section{METHOD}

The study employs qualitative design with interview technique. The technique is used to gain data related to the detailed case study as different from the survey design (Oakley, 1999). A semi-structured interview method is used to obtain detailed information from the respondents (Chua, 2012). The open-ended questioning method was applied during the interview. The questions posed to all the respondents focus on the respondents' experiences and perspectives with regard to the enforcement measures. They are the citizens who are involved in business activities. The respondents' answers led to further in-depth questions. Tables 1 and 2 show the list of the respondents interviewed. 
Table 1. The list of respondents' profile among citizens

\begin{tabular}{|c|c|c|c|c|}
\hline Respondent & Gender & Age (years) & Academic qualification & $\begin{array}{c}\text { Business experience } \\
\text { (years) }\end{array}$ \\
\hline R1 & Male & 33 & PMR & 17 \\
\hline $\mathrm{R} 2$ & Male & 27 & PMR & 11 \\
\hline R3 & Male & 43 & - & 25 \\
\hline R4 & Male & 29 & PMR & 10 \\
\hline R5 & Female & 31 & - & 13 \\
\hline R6 & Female & 37 & - & 20 \\
\hline R7 & Male & 44 & SRP & 24 \\
\hline R8 & Male & 51 & - & 32 \\
\hline R9 & Female & 46 & SRP & 27 \\
\hline R10 & Male & 35 & PMR & 15 \\
\hline R11 & Male & 40 & PMR & 19 \\
\hline R12 & Female & 27 & - & 12 \\
\hline R13 & Male & 36 & - & 21 \\
\hline R14 & Male & 29 & - & 13 \\
\hline R15 & Female & 31 & - & 14 \\
\hline R16 & Male & 47 & SPM & 27 \\
\hline R17 & Female & 56 & - & 37 \\
\hline
\end{tabular}

Note: PMR, SRP, and SPM are national examinations in secondary school.

Table 2. List of respondents' profiles among LG staff

\begin{tabular}{|c|c|c|c|c|c|c|}
\hline Respondent & Gender & Age (years) & $\begin{array}{c}\text { Academic } \\
\text { qualification }\end{array}$ & Position & $\begin{array}{c}\text { Working } \\
\text { experience } \\
\text { (years) }\end{array}$ & $\begin{array}{l}\text { Working experience } \\
\text { in LG (years) }\end{array}$ \\
\hline R18 & Male & 58 & Master & Mayor & 32 & 6 \\
\hline R19 & Female & 36 & Master & K.J.P & 8 & 7 \\
\hline $\mathrm{R} 20$ & Male & 42 & Diploma & K.J.P.N & 6 & 6 \\
\hline R21 & Male & 56 & Master & President & 30 & 3 \\
\hline$R 22$ & Female & 44 & Bachelor & K.B.P & 12 & 10 \\
\hline R23 & Male & 52 & Master & President & 25 & 3 \\
\hline$R 24$ & Female & 51 & Bachelor & K.B.P.N & 29 & 15 \\
\hline $\mathrm{R} 25$ & Male & 58 & Master & President & 32 & 5 \\
\hline$R 26$ & Male & 41 & Bachelor & K.B.P & 12 & 10 \\
\hline R27 & Male & 55 & Certificate & K.B.P.N & 30 & 8 \\
\hline$R 28$ & Male & 53 & Master & President & 37 & 3 \\
\hline$R 29$ & Female & 37 & Diploma & K.B.P & 12 & 8 \\
\hline R30 & Male & 54 & Certificate & K.B.P.N & 29 & 7 \\
\hline
\end{tabular}

The open-ended questioning technique is regarded as an appropriate method used in this study because it allows respondents to explain their views from various perspectives (see Appendix A). Thus, the respondents feel confident, less threatening, and develop trust to respond to the questions freely. Furthermore, the respondents are among individuals involved directly with the enforcement teams and have a huge experience in it. The open-ended interviews enable to obtain comprehensive information from both categories of respondents (Creswell, 2012). The interview process begins with arranging appointments with 17 potential respondents from the citizens representing the sellers involved in the enforcement measures in the LG areas in Kedah state. The interview also included the arrangement of interviews with 13 LG officers from five LG assessed based on the star upgrade system (SSR-LA) (KPKT, 2014; Guest, Namey, \& Mitchell, 2012) following the criteria that encompass the whole main services in the LG (Ministry of Housing and Local Government, 2008). The study employs purposive sampling technique because it allows identifying and selecting the respondents who are knowledgeable on enforcement in LG and willingness to get involved as participants in the study (Patton, 2002; Cresswell \& Plano, 2011). A 
total of 30 respondents from both categories are regarded as sufficient because consistency in the respondents' answers was gathered from the interview (Baker \& Edwards, 2012).

Furthermore, the study is conducted at the microlevel by selection challenges of the enforcement work process as one of LG functions in Kedah state. The selection of enforcement action in Kedah LG as a case study can also represent other LG because the principal act used for reference is equal to all LG in Malaysia, with respect to Local Government Act 1976 (Act 171), Town and Country Planning Act 1976 (Act 172), Drainage and Building Act 1974 (Act 133), and Federal Capital Act 1961, which are the additional references to Kuala Lumpur City Hall (Phang, 1989).

Once the collection of data arising from the interview is completed, the statement of the interview is copied into an interview transcript. Then, data are analyzed from the transcript of the interview. This study uses the analytical method known as taxonomy analysis. This method is seen more appropriately used based on context and also the purpose of the research (Chua, 2012), which is to learn more about the real situation in the enforcement process. Hence, this method is seen to analyze and make information obtained by the relevant themes or sub-themes to understand the cases under study.

The data obtained from both the categories of respondents are further analyzed using the thematic analysis method with the help of an application called ATLAS.ti (Friese, 2019). The thematic method is applied based on these important themes and aims to make it easier for the researcher to determine the main issues raised by both groups of respondents. The data arranged systematically through this thematic method will be able to minimize the lack of information when the analysis is performed (Tracey, 2013). The data from the interview are processed through the segregation of data filtered also labeled according to the coding before being presented (Grbich, 2013; Zukmund, Babin, Carr, \& Grifin, 2013). Data were selected based on the appropriateness of the theme, whereas the irrelevant information was extracted and removed. The themes were developed based on the actual problems faced by the LG in enforcing the laws, especially the issue of arrears of assessment and arrears of license payments. Three main themes have been set, and the data are matched with a study question and are further used to achieve the objectives of the study. The theme, sub-theme, and the data transcripts were sent to respondents to validate the content of the data, which were answers to research questions. Therefore, the findings of the study can be confirmed as being valid and reliable.

\section{RESULTS}

The results of the study obtained from the respondents were analyzed thematically and divided into two perspectives: citizens and LG staff.

\subsection{Citizens' perspective}

From the citizens' perspective, there are three main challenges that are often raised, known as biasness. There are cases of intervention or political agenda and signs of bureaucracy at the LG administrative level. Figure 1 shows the result from the citizens' perspectives on integrity behavior challenges using the application called ATLAS.ti.

\subsection{Local government staff' perspectives}

The researcher imposed further questions to LG staff to get their viewpoint. In general, issues of integrity in terms of LG enforcement can be divided into three, namely, the opportunistic attitude among individuals either on the top of lower-ranked, workforce, and financial issues. Figure 2 shows the results of the interviews across the LG staff on integrity behavior challenges.

\section{DISCUSSION}

Based on the results, it can be established that there are differences in the opinions between both categories of respondents in evaluating the challenges of enforcement team in their work. The analysis of findings discusses the citizens' perspective first before LG staff explains the issues with regard to the objective or constraint of the enforcement measures. 


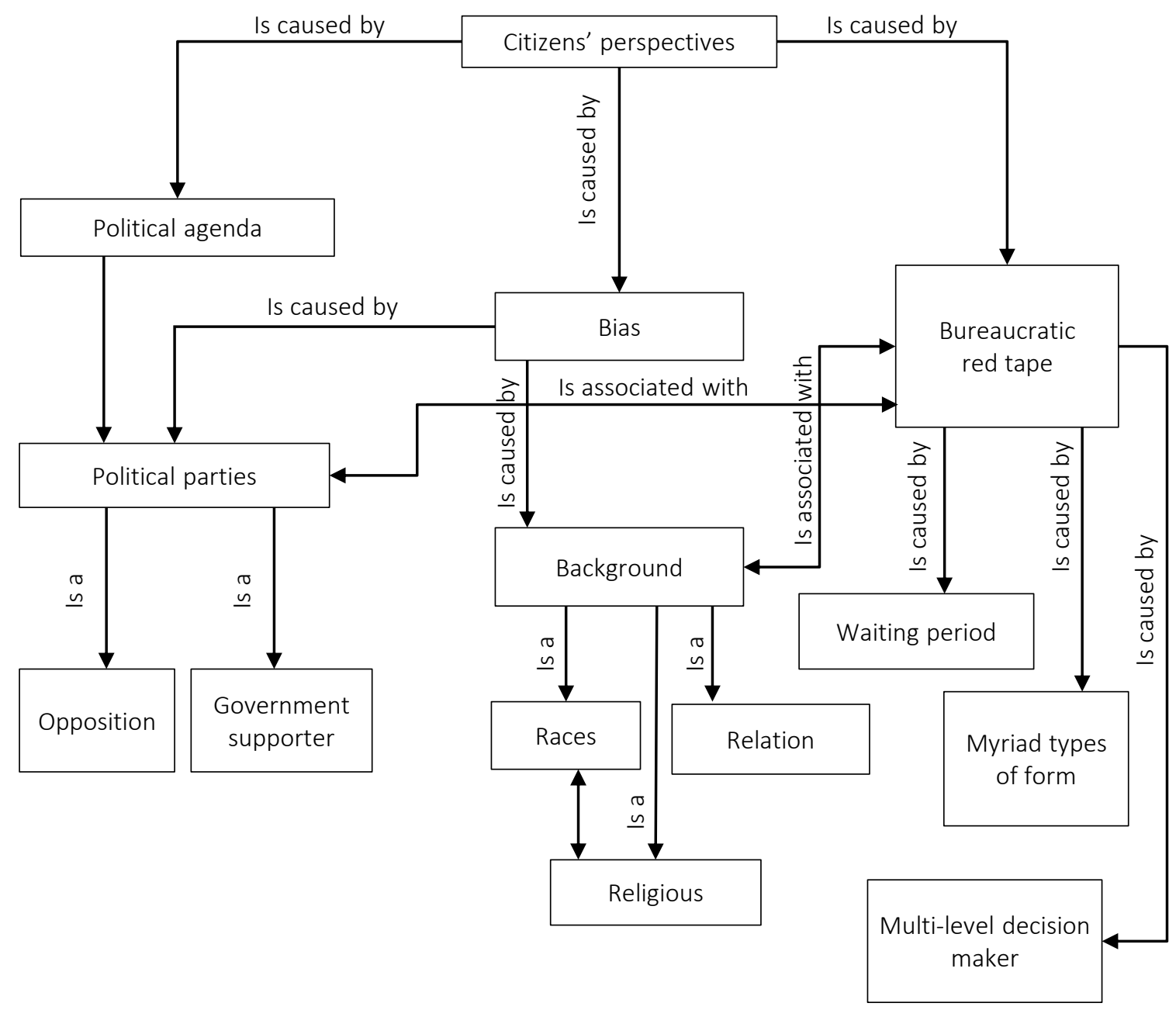

Figure 1. Integrity and enforcement frameworks from the citizens' perspective

\subsection{Citizens' perspective}

The findings from the citizens' perspectives indicate that the enforcement team faces three main challenges: biasness, political agenda and buraucracy, and red tape.

\subsubsection{Biasness}

The issues of unfairness, biasness, or inequality in the services provided to the society have always been raised to LG. The issues not only involve the different ideologies or political stances but also different religions or races have become an issue in the context of enforcing the laws. Based on the feedback given by the citizens, this issue of biasness often occurs because of two main aspects, which are the individual background and different ideology in the political party.
One of the issues of biasness in terms of the background that has always been debated by the sellers or hawkers is about the good relationship between sellers and individuals at the top level of the authority. As explained by several respondents (R1, R4, R8, R9, R13, and R16), they stated that biasness occurs when a seller knows or has a good relationship (like family relations) with individuals at the top. For example, the compound imposed on sellers because of the offenses they committed will be reduced to the minimum level, and even worse, the compound will be waived in the LG system. Reversibly, for sellers who do not know anyone in any level of the LG, they will be imposed with the compound, and their appeal for compound reduction will not be considered. The comment from one respondent is as follows:

"My friend will always be able to know early from others when the authorities want to come up, so 


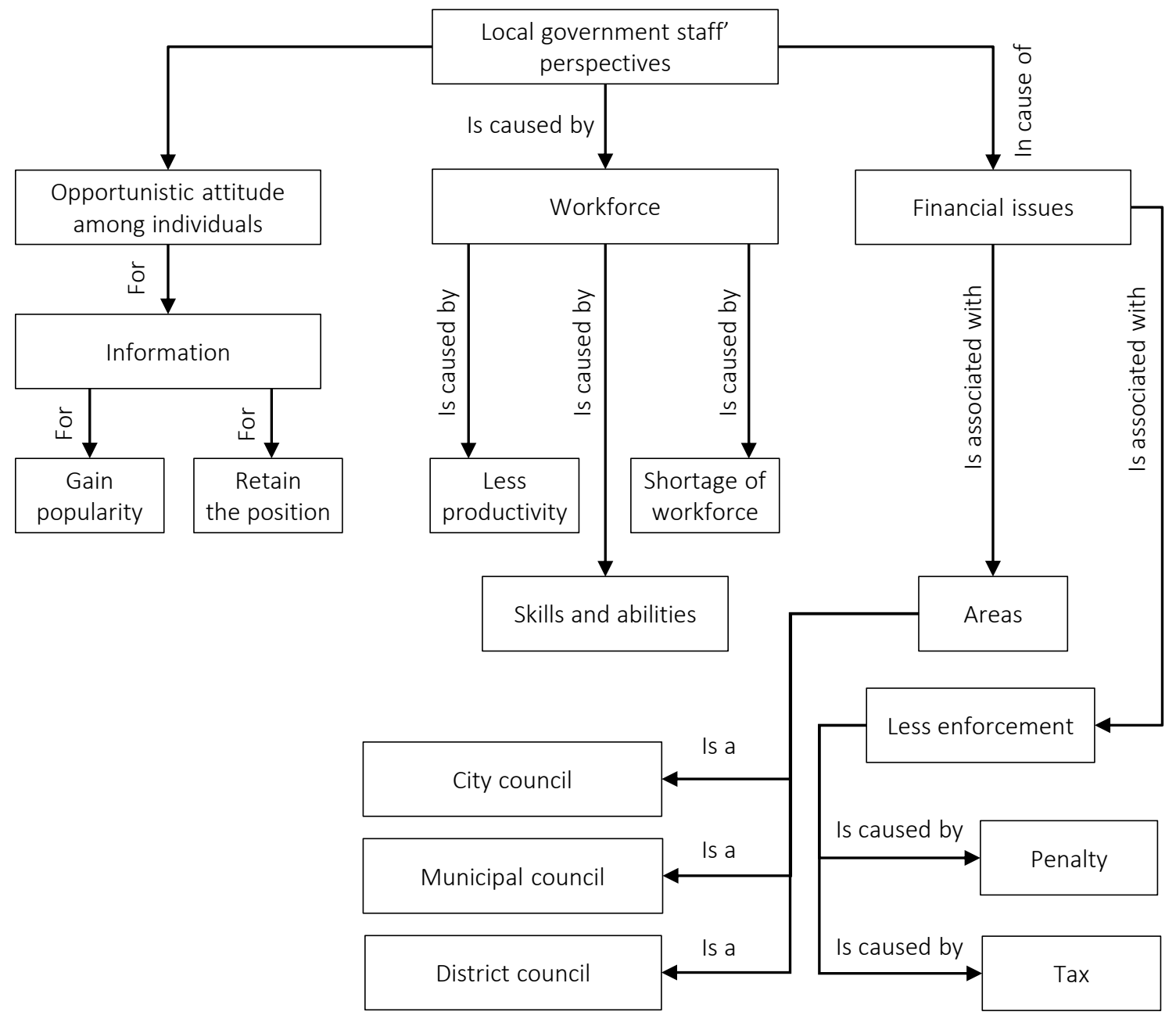

Figure 2. Integrity and enforcement frameworks from LG regulator's perspective

they can take off their stuff early, while others who do not know about it, then their goods will go due to the enforcement" (R1).

Also, it has been noted that the biasness issue is much influenced by the factor of race. Most of the respondents stated that there is a high level of biasness with regard to enforcers' actions in every LG. In the context of Malaysia, the differences in races are often linked with the differences in religions, where Malays are synonymous with Islam, Chinese with Buddhism, and Indians with Hinduism. As an example, R1 and R7 mentioned about sellers in remote areas that the majority of the Malays involved in daily business activities like daily market and night market are often monitored and fined by LG officers as compared to other races of sellers. This issue related to the background is harmonious with the statement made by Danziger (2007) that, in reality, biasness can occur because of the diverse demography or backgrounds of the individuals. Also, biasness can take place because of the ideologies in the political parties, which will be discussed in the following paragraphs. There are few comments from respondents as follows:

"Enforcement personnel should be fair when taking enforcement action to all races" (R5, R8),

"For Malays traders, if they were found guilty, then to who they able to complaint" (R10),

"Why you need to choose, let us be fair to all trades" (R11).

\subsubsection{Political agenda}

In general, the majority of the respondents stated that there is discrimination or biasness caused 
by the different ideologies ingrained in different political parties. This is because there are individuals who aim to achieve their respective political agenda. For instance, from the statements given by R4, R7, R10, R12, and R15, if one has the same political ideology with another person, the enforcement process will be made easier and, in turn, if there are differences in the political ideology, strict measures will be taken, or sellers will have to abide by the complicated processes.

"As we are aware of the majority of the committee meetings which held in the $L G$ will involve the Council Members and therefore most likely information easily spread it to outsiders easily either directly or indirectly" (R12).

Respondents also illustrated that another reason is that the council members are appointed from a group that has the same political ideology. Thus, the information could be delivered among them earlier. As R12 explained, when enforcement measures should be carried out, individuals with the same political ideology will get the information earlier to enable them to act or prepare before the enforcement takes place. In turn, other individuals will be given notice, or their business premises brought down. This shows that the element of biasness happens because of the desire to achieve their political agenda, and this is also in line with the statement made by Danzinger (2007) who explains that in reality, a good management system can be affected because of the political inclination and bias instilled in individuals.

\subsubsection{Bureaucracy and red tape}

Besides the issues of biasness and political agen$\mathrm{da}$, respondents who are the citizens also stated that the enforcement measures demonstrate complex, tedious bureaucracy. R11 and R17 explained that the bureaucracy is among the issues that have complicated them in getting the services required or in applying for license from LG. This makes it difficult to apply and to be imposed with enforcement measures:

"If the office already has a computer facility with complete software and database, the work will be easier and faster, there is no need to find files at the table of other staff or in the boss's room. The situation is getting worst if the officer on leave, so others cannot find the information quickly. On top of that, a few forms need to completed and wait for a certain time to get feedback on license application. Then customers will make a complaint on employees who do not do work well" (R17).

Furthermore, there are also various levels of bureaucracy involved in decision-making. R14 disclosed that he needed to go to various departments in LG to get his business license. The lower-ranked staff must wait for the decision to be made by the top officers who are not always present in the office. The lower-ranked officer must wait to get the signature or approval from the top-ranked officer before delivering the respective services. This causes the delay in the application, and it takes a longer time to complete the application. Also, it is a waste of time for the sellers to make additional visits to $L G$.

\subsection{Local government staff' perspectives}

According to LG staff, there are three main challenges for enforcement team in their work: the opportunistic attitude among individuals, workforce, and financial issues.

\subsubsection{Opportunistic attitude among individuals}

With regard to the statements made by the LG staff, the restriction in enforcement measures is caused by the opportunists from top management. Top management teams are individuals who design the information and well acquainted with the LG activities yearly. This gives them the advantage to channel the information to their favored groups. This information channeling aims to enable relevant parties to make an early preparation before any enforcement measures are carried out. For example, with the advanced delivery of information by these opportunists, this enables certain people to escape any fines or actions by the LG when the enforcement is carried out. Automatically, this relationship between the information deliverer and the stakeholders will further increase the popularity of the individuals and subsequently enable them to retain their positions in LG or politics (R26, R27, R29, and R30). 
R26 asserts that

"Usually, some council members are directly involved with certain businesses, and there are also council members who apply to me that certain individuals manage the project."

The statements given earlier shows an opportunity among the council members in LG, but still follow certain financial procedures in project implementation. R30 also acknowledged the matter and agreed to the fact that

"There are several types of approvals for any work that can be offered directly to individuals without a process of tender, but financial procedures are adhered to."

\subsubsection{Workforce}

It cannot be denied that the enforcement limitation is explained by the shortage of workforce in LG. This is because the area of LG is wide and makes it difficult for LG to monitor the duties effectively. For instance, bigger remote areas are heavily populated by Malays, and when the enforcement operations are completed, the people mostly subjected to the compounds are Malays who sell in the night or daily markets. Most officers (R19, R20, R21, R22, R24) stated that there is no issue of biasness in terms of race, but it is based on the geographical locations and the shortage of efficient staff to carry out the enforcement duties:

"The staff at the local government would have to say that the internal exchange will occur some problems even if it can eventually do too. The reason for staff is to be comfortable with work and friends and not interested in job rotation. They are more willing to work at the same place even if they have done the same work for long time. If the rotation needs to follow due to job promotion, then it will be ok, but it will be problematic in the beginning as many people do not want to move to another workplace" (R19).

"This is common that we face the comments and advice from people to ask for additional staff, but the lack of staff is our constraints here" (R20).

R22, R23, and R24 also agreed with the statement with the following comment:
"In the issue of lack of staff due to a limited number of job position approved, sometimes the vacancy is not filled due to overhead costs, utility and even LG there is no new revenue to strengthen the financial position of LG unless The State or Federal Government. Due to financial incapability, the worries are LG unable to pay the salary to its staff, which is more problematic when compared to grievances from outside persons; there is no other way unless ithere is a need to do enforcement action."

Further, it has also disclosed that the enforcement officers have a key issue with respect to their skills and abilities in carrying out their duties. Most of the respondents from LG (R19, R20, R22, R23, $\mathrm{R} 24)$ stated that during the interview process, the enforcement officers would be chosen in terms of their fitness and stamina with total disregard for skills and other abilities, which can help in the enforcement measures. As an example, an enforcement officer is seen to have the ability to carry out the enforcement operations, but he/she is not skillful in preparing the reports as lacking the skills in ICT. This would be an issue as preparing a report is an important aspect of the job as it provides the source of information to the top management (R19, R21).

It has been revealed that the enforcers are not skilled in convincing and persuading the sellers in difficult situations. This indicates that lack of skills in public relations to the point that an enforcement operation that is supposed to be easy becomes complicated and would further exacerbate the situation (R19, R20, R21, R22, R24). The issue of the workforce is also related to the officers' skills in giving productive outcomes. This is because those who have long served tend to show deteriorating work productivity as they have been doing the same kind of task for a long time (R18 to R25).

\subsubsection{Financial issues}

The next factor that contributes to the restriction of the enforcement agency is the financial state of LG. The area or the type of LG is the reason behind the different financial state among LGs. This is because the financial allocations obtained from the ministry are different from one to another LG. The allocation is based on the type of LG, namely 
the district council, city council, and town council. Although the financial position is different, the problem faced by all LGs is almost similar. For example, the fund allocated by the ministry to the district council is higher as compared to the city or town council (particularly, allocation on area clearing). Nonetheless, the financial affordability for the town and city councils are seen to be still able to generate their incomes despite the differences in allocations. This is due to the officers' credibility at these levels who are more efficient in generating the income, compared to those serving in the district council. Thus, the district council is seen to have less ability in enforcement issues compared to other two councils as the allocation that they obtain is only for area clearing and cleaning (R18, R21, R23, and R25) can be stated as follows:

"Continuous monitoring is very good, but the issue is always the barriers to $L G$ is the constraints of staff to monitor the overall additional regulatory areas with a broad regulatory area and limited personnel; all this will affect the effectiveness enforcement itself."

Due to this financial constraint, the positions at each LG have not been increased, whereby at the district council level, the law officers' position at
Grade L29 as compared to experienced officers at town council with a higher grade, which is L44. As a result, the district council will take a longer time in enforcing or resolving enforcement issues because they are less exposed and lack the experience as compared to those in the city and town councils (R22, R24, R26, R28). Following the lack of enforcement in the district council, the outstanding assessment has increased, and the compound fine is seldom imposed, in comparison to LG at the town or city council levels. In terms of the various forms to be filled in by LG service applicants, they are part of the black and white procedure required for documentation in the legal process, to the phase of impeachment because definitely, every LG service would require some allocation of funds (R19, R22, R26, R29).

"The cost of management is different between each $L G$ because, in Kedah, three types of $L G$ are city council, municipal council, and district council, and, definitely, the criteria on each type of LG are not the same. Besides, the cost of management depends on the number of staff at each LG. If there are much staff, then hig the cost of management is high, and as many things should be seen and supervised as possible."

\section{CONCLUSION}

Therefore, based on the present study, it can be understood that there are different perspectives from the citizens' standpoint on the staff or officers who perform their duties in LG. The citizens are more concerned with surrounding issues that happen without accounting for other factors. This is because they do not know or even have access to the internal information in LG. Every action of LG or the objective behind the enforcers' actions is done beyond their knowledge. Thus, whether it is good or bad, weak or efficient, management is assessed only based on the surrounding, without taking account the constraints faced by LG. Nonetheless, the views of the citizens are important to assess the LG management for further improved services, and the constraints overcome comprehensively to ensure that the services and enforcement can be carried out efficiently and effectively.

Based on the study, several suggestions in improving the process of enforcement can be considered to be implemented. In general, all actions of the enforcers must be dynamic based on the local situations and conditions; thus, the use of the Really Responsive Risk-based Regulation Theory to be applied in the enforcement. To ensure that the theory is successful, the enforcement officers should develop the soft skills, employability skills, and academic skills to enable them to understand current situations and the steps that should be taken to deal with the issues at hand. These officers must take the initiative to cultivate a learning environment and develop a diverse range of skills or abilities to carry out multi-tasking and not only focused on how to enforce actions. Internal reshuffling, with officers doing new tasks through the exchange of portfolios in LG, should be able to increase their efficiency. Areas for allocation of the hawkers should be planned strategically to enable effective and efficient monitoring and easy enforce- 
ment. The government should introduce improved ICT facilities, going paperless and environmentally friendly approaches to be considered, such as data storing technology through the ICT system. All these processes should be able to increase the LG enforcement integrity and automatically boost the image of LG in the society in the context of excellent services. The recommendation for future studies is to revisit the facilities and legislation used by LG in ensuring the regulators are compliant with the code of integrity. Besides, future studies also can use the results of the study to form research instruments for quantitative study such as the formation of questionnaires. The questionnaire was used to obtain the perception of staff and the public, and generalization can be made to the entire LG in a country involved.

To further strengthen the monitoring aspect, the involvement of all parties is a must to ensure the journey of a process is progressing as in the prescribed procedure. Wahani, Hakim, Soeaidy, and Noor (2014) see the aspect of monitoring not only from the top corner to the bottom but also the monitoring needs to be seen from the ground corner up to ensure a procedure is observed at each level, and indirectly the intervention of certain agencies will not be arbitrary.

\section{REFERENCES}

1. Ahmad Sarji Bin Abdul Hamid (1996). Circulars on Administrative Reform in The Civil Service of Malaysia (1991-1996). Kerajaan Malaysia.

2. Alam, M. M., Johari, R. J., \& Said, J. (2018). An empirical assessment of employee integrity in the public sector of Malaysia. International Journal of Ethics and System, 34(4), 458-471. https://doi.org/10.1108/ IJOES-01-2018-0006

3. Ali, N., \& Abdullah, M. A. (2012). The food consumption and eating behaviour of Malaysian urbanites: Issues and concerns. Geografia Malaysia Journal of Society and Space, 8(6), 157-165. Retrieved from http://journalarticle.ukm. my/5608/

4. Ayres, I., \& Braithwaite, J. (1992). Responsive Regulation: Transcending the Regulation Debate. New York: Oxford University Press. Retrieved from https://www.amazon.com/Responsive-Regulation-Transcending-Deregulation-Socio-Legal/ dp/0195093763

5. Baker, S. E., \& Edwards, R. (2012). How many qualitative interviews is enough? Expert voices and early career reflections on sampling and ceases in qualitative research. National Centre for Research Methods. Retrieved from http:// eprints.ncrm.ac.uk/2273/4/how_ many_interviews.pdf
6. Baldwin, R., Cave, M., \& Lodge, M. (2012). Understanding Regulation: Theory, Strategy and Practice. New York: Oxford University Press. Retrieved from https://www.oxfordscholarship. com/view/10.1093/acprof:oso bl/9780199576081.001.0001/ acprof-9780199576081

7. Beaglehole, J. H. (1976). The District: A Study in Decentralization in West Malaysia (Issue 6 of Hull monographs on South-East Asia). University of Hull.

8. Binh, P. D. (2014). Provincial Monitoring and Control System in Vietnam: Case Study of Hai Duong Province. International Journal of Economics and Finance, 6(4), 220-227. Retrieved from https://www.researchgate.net/ publication/272805635_Provincial_ Monitoring_and_Control_System_in_Vietnam_Case_Study_of_ Hai_Duong_Province

9. Black, J., \& Baldwin, R. (2010). Really responsive risk-based regulation. Law and Policy, 32(2), 181-213. Retrieved from http:// eprints.lse.ac.uk/27632/

10. Boyd-Swan, C. H., \& Molina, A D. (2019). Public Service Integrity and the Quality of Governance: Examining the Role of CitizenAdministrator Value Congruence. Public Integrity, 21(3), 229-247. https://doi.org/10.1080/10999922.2 018.1453912
11. Chua, Y. P. (2012). Kaedah dan Statistik Penyelidikan: Asas Statistik Penyelidikan (Buku 2). Kuala Lumpur: McGraw-Hill Education.

12. Colquitt, J. A., \& Salam, S. C. (2009). Foster Trust through Ability, Benevolence and Integrity. In E. A Locke (Ed.), Handbook of Principles of Organization Behavior: Indispensable Knowledge for Evidence-based Management (pp. 389-404). John Wiley \& Sons Ltd. Retrieved from https:// www.econbiz.de/Record/fostertrust-through-ability-benevolence-and-integrity-colquittjason/10003867251

13. Cresswell, J. W., \& Plano, C. V. L. (2011). Designing and conducting mixed method research (2nd ed.). SAGE; Thousand Oaks, CA. Retrieved from https:// books.google.com.ua/books/ about/Designing_and_Conducting_Mixed_Methods_R. html?id=YcdlPWPJRBcC\&redir esc $=y$

14. Creswell, J. W. (2012). Educational Research, Planning, Conducting and Evaluating Quantitative and Qualitative Research (4th ed.). Boston: Pearson Education Inc.

15. Danziger, J. N. (2007). Understanding the Political World: A Comparative Introduction to Political Science (8th ed.). New York: Pearson Longman. 
16. Erakovich, R., \& Kolthoff, E. (2016). Analysis of Ethical Leadership and Integrity Development in Local Government: The United States. The Netherlands, Montenegro, and Serbia. International Journal of Public Administration, 39(11), 872-882. Retrieved from https://www.researchgate.net/ publication/301794979_Analysis_of_Ethical_Leadership_and_ Integrity_Development_in_Local_Government_The_United_ States_The_Netherlands_Montenegro_and_Serbia

17. Friese, S. (2019). ATLAS.ti 8 Windows - User Manual - updated for program version 8.4. ATLAS.ti Scientific Software Development GmbH. Berlin: Germany.

18. Grbich, C. (2013). Qualitative Data Analysis: An Introduction (2nd ed.). SAGE Publications Ltd. London: UK. Retrieved from https://www.amazon.com/ Qualitative-Data-Analysis-CarolGrbich/dp/1446202976

19. Guest, G., Namey, E. E., \& Mitchell, M. L. (2012). Collecting Quantitative Data: A Field Manual for Applied Research. Thousand Oaks: Sage Publication.

20. Houston, D., \& Harding, L. H. (2013). Public trust in government administrators: Explaining citizen perceptions of trustworthiness and competence. Public Integrity, 16(1), 53-75. Retrieved from https://www.tandfonline.com/doi/ abs/10.2753/PIN1099-9922160103

21. Huberts, L. (2014). The integrity of governance: What it is, what we know, what is done, and where to go. Basingstoke, UK: Palgrave Macmillan.

22. Javier, F. (2007). Assessing corruption - An analytical review of corruption measurement and its problems: Perception, error and utility. Retrieved January 2, 2008 from https://pdfs.semanticscholar. org/d74e/a1f48199718aabe62e5635ba1a73c480b90c.pdf

23. Jiménez, F., García-Quesada, M., \& Villoria, M. (2014). Integrity Systems, Values, and Expectations: Explaining Differences in the Extent of Corruption in Three
Spanish Local Governments. International Journal of Public Administration, 37(2), 67-82. https://doi.org/10.1080/01900692. 2013.836666

24. Keane, A., Jones, J. P. G., EdwardsJones, G., \& Milner-Gulland, E. J. (2008). The Sleeping Policeman: Understanding Issues of Enforcement and Compliance in Conservation. Animal Conservation, 11(2), 75-82. https://doi.org/10.1111/j.14691795.2008.00170.x

25. Kolthoff, E., Erakovich, R., \& Lasthuizen, K. (2010). Comparative analysis of ethical leadership and ethical culture in local government: US, Netherlands, Montenegro and Serbia. International Journal of Public Sector Management, 23(7), 596-612. https://doi. org/10.1108/09513551011078879

26. KPKT Policy and Inspectorate Department. (2014). The Star Rating System.

27. Laporan Pembahruan dan Kemajuan dalam Perkhidmatan Awam (2000). Perkhidmatan Awam Malaysia: Memperkukuh Agenda Pembaharuan. Malaysia: Unit Pemodenan Tadbiran dan Perancangan Pengurusan Malaysia (MAMPU). Retrieved from http:// malcat.uum.edu.my/kip/Record/ ukm.vtls000312117

28. Macrory, R. (2006). Regulatory Justice: Making Sanctions Effective. Bloomsbury: London. Retrieved from https://webarchive.nationalarchives.gov. uk/20121205164501/http:/www. bis.gov.uk/files/file44593.pdf

29. Manaf, H. A., Armstrong, S. J., Lawton, A., \& Harvey, W. S. (2018). Managerial tacit knowledge, individual performance, and the moderating role of employee personality. International Journal of Public Administration, 41(15), 1258-1270. https://doi.org/10.1080 /01900692.2017.1386676

30. Manaf, H. A., Mohamed, A. M., \& Lawton, A. (2016). Assessing public participation initiatives in local government decisionmaking in Malaysia. International Journal of Public Administration,
39(11), 812-820. Retrieved from https://www.researchgate.net/ publication/291391655_Assessing_Public_Participation_Initiatives_in_Local_Government_Decision-Making_in_Malaysia

31. McLeod, R., \& Harun, H. (2014, May). Public Sector Accounting Reform at Local Government Level in Indonesia. Financial Accountability \& Management, 30(2), 238-258. https://doi. org/10.1111/faam.12035

32. Menzel, D. C. (2015). Research on Ethics and Integrity in Public Administration: Moving Forward, Looking Back. Public Integrity, 17(4), 343-370. https://doi.org/10.1 080/10999922.2015.1060824

33. Ministry of Housing and Local Government. (2008). Circular from the Head of Secretary.

34. Mohamad, M. H., Daud, Z., \& Yahya, K. K. (2014). Prediction of transformational leadership on employees' good governance in Malaysian local government authorities: A pilot study. International Journal of Management Research and Review, 4(2), 163-171. Retrieved from https://www.semanticscholar. org/paper/INTERNATIONAL-JOURNAL-OF-MANAGEMENT-RESEARCHAND-OF-Mohamad-Daud/ dcb55038eebfcacac7ffe36932c732d87c8816ae

35. Mohamad, M. H., Daud, Z., \& Yahya, K. K. (2016). The influence of leadership styles on subordinates' integrity in Malaysia local authorities: The mediating role of trust. Pertanika Journal of Social Science and Humanities, 24, 119-131. Retrieved from https://www.researchgate.net/ publication/311277254_The_influence_of_leadership_styles_on_ subordinates'integrity_in_Malaysian_local_authorities_The_mediating_role_of_trust

36. Nabatchi, T. (2012). Putting the "public" back in public values research: Designing participation to identify and respond to values. Public Administration Review, 72(5), 699-708. https:// doi.org/10.1111/j.15406210.2012.02544.x 
37. Ngah, K., Zakaria, Z., Mustaffa, J., \& Sawal, M. Z. H. M. (2011) The future challenges of local authorities in Malaysia: A case study in Seberang Perai. African Journal of Business Management, 5(26), 108-141. Retrieved from https://www.researchgate.net/ publication/266874397_The_future_challenges_of_local_authorities_in_Malaysia_A_case_study_ in_Seberang_Perai_Penang

38. Noon, M. (2010). The shackled runner: Time to rethink positive discrimination? Work, Employment and Society, 24(4), 728-739. https://doi.org/ 10.1177\%2F0950017010380648

39. Oakley, A., Hood, S., Mayall, B., \& Oliver, S. (Eds.). (1999). People's Way of Knowing, Gender and Methodology: Critital Issues in Social Research. Buckingham: Open University Press.

40. Patton, M. Q. (2002). Qualitative research and evaluation methods (3rd ed.). SAGE Publications. Thousand Oaks, CA.

41. Pekeliling Kemajuan Pentadbiran Awam Bil.1 Tahun (2001). Garis Panduan Pelaksanaan Penandaarasan Dalam Perkhidmatan Awam. Malaysia:
Unit Pemodenan Tadbiran dan Perancangan Pengurusan Malaysia (MAMPU).

42. Phang, S. N. (1989). Sistem Kerajaan Tempatan di Malaysia. Dewan Bahasa dan Pustaka, Kuala Lumpur.

43. Phang, S. N. (2008).

Decentralisation or recentralisation? Trend in local government in Malaysia. Commonwealth Journal of Local Government, 1, 126-132. https:// doi.org/10.5130/cjlg.v1i0.759

44. Rosenbloom, D. H., Kravchuk, R. S., \& Clerkin, R. M. (2014). Public Administration: Understanding Management, Politics and Law in the Public Sector (8th ed.). New York: McGraw-Hill Education.

45. Rosli, M. H., Abd Aziz, M. A., Mohd, F., \& Said, J. (2015). Integrity system in Malaysian public sector: An empirical finding. Procedia Economic and Finance, 28, 260-265. https://doi.org/10.1016/ S2212-5671(15)01109-0

46. Said, J., Alam, M. M., \& Khalid, M. A. (2016). Relationship between good governance and integrity system: Empirical study on public sector of Malaysia. Humanomics,
32(2), 151-171. Retrieved from https://www.researchgate.net/ publication/303977450_Relationship_between_good_governance_ and_integrity_system_Empirical_study_on_the_public_sector_of_Malaysia

47. Tracey, S. J. (2013). Qualitative Research Methods. WileyBlackwell.

48. Wahani, R. J. V., Hakim, A., Soeaidy, S., \& Noor, I. (2014). The Implementation of Corruption Prevention Policies: A Study on Municipal Government of Surakarta. Interdisciplinary Journal of Contemporary Research in Business, 6(5), 9-17. Retrieved from http://euabr.com/ ijcrbsep14/9-17sep14.pdf

49. Yulk, G. (2009). Leading Organizational Learning: Reflections on Theory and Research. Leadership Quarterly, 20(1), 49-53. https://doi. org/10.1016/j.leaqua.2008.11.006

50. Zukmund, W. G., Babin, B, J., Carr, J. C., \& Grifin, M. (2013). Business Research Methods. South-Western: Cengage Learning.

\section{APPENDIX A}

\section{Example of public view questions}

1. Describe how well is your understanding of enforcement operations implemented by the local government?

2. In your opinion, will the enforcement personnel provide a fair service to all parties? Yes/ No. Comment.

3. Please indicate your proposal for improvement of enforcement so that enforcement can be carried out smoothly and properly and fair to all parties.

\section{Example of staff' view questions}

1. As a civil servant who is involved with enforcement in the local government, how did you ensure that the enforcement personnel under your supervision have clearly understood the steps to be taken in the enforcement? Please describe the method.

2. In the event of an unexpected incident occurring during enforcement, will the enforcement personnel be informed of the steps to be taken? Yes/No. Please indicate that the method is based on the operation implemented.

3. In your opinion, is the existing guidelines updated in accordance with the current situation in implementing enforcement? Give your views. 